\title{
IRISH FILM AND MEDIA STUDIES PUBLICATIONS
}

\author{
THE YEAR IN REVIEW - 2019 \\ Ciara Chambers (ed.)
}

Copyright (c) 2020 by the authors. This text may be archived and redistributed both in electronic form and in hard copy, provided that the author and journal are properly cited and no fee is charged for access.

\section{Introduction}

Ciara Chambers .278

Irish Cinema in the Twenty-First Century.

Ruth Barton

Loreta Goff

The Historical Dictionary of Irish Cinema, $2^{\text {nd }}$ edition.

Tony Tracy and Roddy Flynn

Stephen Boyd .284

A Post-Nationalist History of Television in Ireland.

Edward Brennan

Stephen Goulding. .287

Media Law in Ireland, $2^{\text {nd }}$ edition.

Eoin Carolan and Ailbhe O’Neill.

Maria O’Brien .290

Gaelic Games on Film: From Silent Film to Hollywood Hurling, Horror and the Emergence of Irish Cinema.

Seán Crosson.

Denis Condon. 


\section{Introduction}

\section{Ciara Chambers}

This has been a big year for important books on Irish film with the publication of Ruth Barton's Irish Cinema in the Twenty-First Century (Manchester University Press), Seán Crosson's Gaelic Games on Film (Cork University Press) and the revised second edition of the Historical Dictionary of Irish Cinema (Roddy Flynn and Tony Tracy, Rowman \& Littlefield). The ubiquity of Saoirse Ronan is evidenced in the covers of two of these volumes, both featuring her performance in Brooklyn (John Crowley, 2015) with a reminder that Irish film occupies a significant space in the contemporary international cinematic arena.

In her much-welcomed exploration of the contemporary Irish cinematic landscape Ruth Barton takes up where her seminal 2004 study Irish National Cinema left off. In her review of the book, Loretta Goff raises the very notion of what it means to be "Irish" in a globalised arena, outlining how Barton grapples with this question in Irish Cinema in the Twenty-First Century. The monograph builds on Barton's previous study by exploring the rapid technological, representational and sociological changes to the Irish film industry in the last fifteen years. Barton's expansive work taps into the thematic complexity of Ireland onscreen and off to touch on politics, identity, ethnicity, gender, genre, aesthetics and landscape. The richness of her study makes the case for the importance of nurturing a local film industry to represent the many intricate stories associated with the island, north and south, and of scrutinising these representations as Ireland reconsiders its position within Europe and the rest of the world. The coming years will no doubt yield many opportunities and challenges to consider in depicting post-Brexit Ireland, with a functioning Assembly in the North and a reconstituted government in the South. As Goff notes, it is a challenge to "locate a distinctive Irish cinema in an era of co-productions that often defy local or national classifications" and Barton usefully explores the conditions and outputs associated with a range of funding modules. It is also helpful that her study of feature productions (considering narrative, documentary and animation) is punctuated by analyses of seven short films, chosen to echo the thematic structure of each chapter of the book. This highlights the importance of the short film not just as a "stepping stone" for nascent directors, but as a significant art form worthy of study in and of itself.

Denis Condon considers how Seán Crosson's Gaelic Games on Film explores the relationship between Gaelic games and cinema from the early 1900s through to the twentyfirst century. Condon contextualises various modes of screen depiction highlighting the differences between film and video formats and outlining how Crosson demonstrates "that television coverage has adopted cinematic modes of representation" in its depiction of Gaelic sports. Crosson's substantial work draws on a range of archival material to consider the representation of Gaelic football, hurling and camogie in newsreels, documentaries and feature films produced both locally and internationally. Crosson notes that "Gaelic games have provided on occasion a shorthand for regressive stereotypes associated with Irish people, including their alleged propensity for violence. For indigenous producers, on the other hand, Gaelic games provided distinctive Irish cultural practices and as such were employed to promote and affirm the Irish nation, particularly as an indigenous film culture began to develop in the aftermath of the Second World War" (15). By exploring these competing depictions, this study transcends the world of world of sport to consider issues such as national identity, and the role that cultural representations play in cementing community and both endorsing and challenging stereotypes.

Stephen Boyd delves into the second edition of The Historical Dictionary of Irish Cinema by Roddy Flynn and Tony Tracy. Noting an impressive additional 264 pages, almost 
doubling the original incarnation of the book in 2007, Boyd outlines how this updated version "provides the reader with a wider range of entries and references than its previous incarnation whilst also updating existing entries". The tome offers the reader what internet databases cannot: the academic knowledge and critical contexts that are invaluable when approaching the complexity of the history and development of Irish film. Indeed, the authors usefully define their application of the concept of Irish cinema when compiling entries considering both form and production contexts in doing so. The volume considers not just the films which might constitute a national cinema but the cast, crew, policies, funding initiatives and financial circumstances that shape the filmmaking landscape. It will no doubt become core reading for all current and future scholars in the field.

In addition, Irish television also features in this year's publications. Stephen Goulding explores Edward Brennan's challenge to the institutional histories of Irish broadcasting in $A$ Postnational History of Television in Ireland (Palgrave). Combining personal interviews and newspaper analysis, Brennan's narrative overturns the "orthodox history" of the impact of television on the Irish psyche, suggesting that incidents capitalised upon in the press did not necessarily impact on viewers in the ways recorded by traditional histories that did not engage with audience research. Brennan also asserts that previous histories have been too local in focus and too broadcaster-centric, missing the transnational impact of the development of television, particularly in an Ireland with ongoing engagement with British and American representations. As Goulding argues, Brennan's 'findings point toward the need for further research in this area and the necessity to capitalise on what is a diminishing academic resource: the memories and recollections of the medium's early enthusiasts and interactants".

Maria O'Brien welcomes the second edition of Media Law in Ireland (Bloomsbury), which concentrates on broadcast media and excludes issues pertaining to new media due to the speed of change in this area. O'Brien contextualises the importance of media law issues in the cultural sphere by referring to just some of the recent areas of debate such as "blasphemy, the funding of public service media, and regulation of political advertising". As O'Brien outlines, the book grapples with some of the fundamental values of expression in any democratic society: "the balancing act between the protection of free speech, the freedom of the press, and the role of the state towards the operation of the media". O'Brien raises the important question of political advertising in relation to the ban implemented on broadcasting by the 2009 Broadcasting Act, a ban which does not extend to print or the internet. Twitter has announced that they will not accept political advertising in an act of self-censorship that has long been associated with mass entertainment media (even going back to cinema newsreels). This study helpfully positions entertainment practices within the legal contexts that shape production and reception.

It is also worth mentioning Reporting the Troubles (Blackstaff Press), compiled by Deric Henderson and Ivan Little with a foreword by Senator George Mitchell, US Special Envoy for Northern Ireland (1995-2001). Published at the end of 2018, the edited collection gathers the stories of local and international journalists who reported on the Troubles for a range of newspapers and broadcasters. Just some of the sixty-six contributors are Kate Adie, Wendy Austin, Martin Bell, Anne Cadwallader, Paul Clark, David Davin-Power, Robert Fisk, Tommie Gorman, Eamon Holmes, Gloria Hunniford, Jane Loughrey, Eamonn Mallie, Susan McKay, Bill Neely, Miriam O'Callaghan, Martina Purdy, Gail Walker and Nicholas Witchell.

In many ways, the book is a compendium of horrors, charting the litany of atrocities that were reported around the world. Many of these were significant news stories that will still resonate with readers today: Bloody Sunday, Bloody Friday, the Enniskillen, Shankill and Omagh bombings, the shootings in Loughanisland and Greysteel. The list goes on and on and we are also reminded that there are many more incidents that go unremembered. In recounting his coverage of the death of Daniel Carville, father of five, shot while shielding his young 
son, Denis Murray reminds that "one of the greatest tragedies of the Troubles was all those forgotten deaths, so many of them" (59). Susan McKay recounts her own relationship with her children as she leaves them to go to report on the conflict: "they'd cling to my legs at the front door as I went out to work. I'd prise their little hands off, tell them I'd be back soon and kiss them goodbye. I'd feel torn" (173). She goes on to recount her reporting of the sectarian murder of another child, sixteen-year old James Morgan, beaten to death, set on fire and dumped in a pit. McKay recalls the chilling words of the boy's father: "I only hope the first hammer blow killed him" (174). The Orangeman convicted of the killing was not expelled from the order and was released eighteen months into his prison sentence under the terms of the Good Friday Agreement. These accounts raise the spectre of other youths: the children killed and maimed in shootings or bomb blasts; the children who witnessed the deaths of their parents; the children who died by suicide after punishment beatings; the children who lived on with loss and grief and life-changing injuries.

Deeply moving, it is a book that incites rage at all that was endured and reminds the reader of the various repugnant versions of inhumanity that proliferated amongst the paramilitaries, the politicians and the public throughout the conflict and beyond. It is a book that is deeply evocative and at times surprisingly honest as various reporters record their most vivid recollections of covering events in Northern Ireland. It also raises the darker side of media coverage: some accounts are self-congratulatory; others recount excitement and adrenalin in covering horrific incidents; some defend the necessity of disturbing grieving families so their stories may be shared. Many consider their own humanity in this process and there are some writers who were driven to leave the profession because of the horrors they observed. There are other journalistic discussions about ethics and integrity, propaganda, censorship and collusion but the dominant message of this book is a reminder, eloquently outlined by Gail Walker, of "the lives that were stopped. The lives of loved ones suspended in grief. The hearts that cry out yet for some form of justice. The hope of closure" (220).

There are moments of course, that are intended to be uplifting, to break the resounding death rattle: the signing of the Good Friday agreement, the "touch of magic as Hume and Trimble collect their Nobel Peace Prize" (190), the grotesquerie of the "Chuckle brothers". But it is the horror that remains, long after reading. This is an important book and one that will have relevance not only to journalists and media scholars, but to anyone interested in hearing what it was like, on both sides of the camera, for those who watched from near and far and especially for those lucky to have survived but unfortunate enough to have lived through some or all of the Troubles. It is a book of abject suffering and unspeakable loss and should be treated with care by its reader.

\section{Works Cited}

Henderson, Deric and Ivan Little, eds. Reporting the Troubles. Belfast: Blackstaff Press, 2018.

Ciara Chambers is Head of the Department of Film and Screen Media, University College Cork, a member of the Council of the International Association of Media and History, author of Ireland in the Newsreels (Irish Academic Press, 2012), co-editor of Researching Newsreels: Local, National and Transnational Case Studies (Palgrave, 2018), screenwriter and associate producer of the six-part television series Éire na Nuachtscannán (TG4 www.irelandinthenewsreels.com).

ciara.chambers@ucc.ie 
Irish Cinema in the Twenty-First Century.

Ruth Barton

Manchester: Manchester University Press, 2019. 248 pp.

ISBN: 9781526124449

Reviewer: Loretta Goff (University College Cork, Ireland)

The last few decades have seen Ireland undergo significant change, with the economic rise and downfall of the Celtic Tiger period, shifting tides of emigration and immigration, and resultant socio-political transformations. As a result of Ireland's rapid globalisation during this period, persistent questioning of what it means to be "Irish" has entered public debate in recent years. The same question can be applied to the nation's cinema, and is one that Ruth Barton grapples with in Irish Cinema in the Twenty-First Century, updating her previous monograph on the topic, Irish National Cinema (2004) to reflect the changes in both Irish society and the Irish film industry since that publication. Barton's focus in Irish Cinema in the Twenty-First Century thus expands to include the emergent success of Irish horror, animation and short film, as well as to highlight the underrepresented role of women across the Irish film industry.

Structurally, Barton gives weight to the previously less-discussed areas of Irish cinema in her monograph. After providing context with an overview of the production (including funding, audiences, politics and classification) of Irish film in Chapter 1, Barton gives precedence to animation (Chapter 2), horror (Chapter 3), and documentary (Chapter 4), before moving on to revisit and elaborate on the areas of history and trauma (Chapter 5), posttroubles Northern Ireland (Chapter 6), rural Ireland (Chapter 7) and the city (Chapter 8). Uniquely, and importantly, she intersperses these chapters with brief analyses of seven short films. Short film production proliferates in Ireland and plays an important role for Irish filmmakers, particularly for those getting a start in the industry as these films often act as an entry point for funding. However, despite this and the international success of many of these films, with several receiving Academy Award nominations (including Late Afternoon [2017] and Detainment [2018] most recently), academic analysis in this area remains limited (though the site Gearr Scannain, an offshoot of Irish film site Scannain, does offer an online platform for short films). While a chapter is not dedicated to short films here, they are brought to prominence through these dedicated spaces between chapters wherein Barton's analysis of them functions as a thread to weave the sections together. In this way, increased attention is drawn to the shorts and the reader is able to reflect on how they fit within the broader themes of the work as a whole.

Also woven throughout Irish Cinema in the Twenty-First Century, rather than given chapters of their own are the roles of gender, ethnicity and other aspects of identity in Irish film. As Barton notes in the introduction, "questions of Irish identity/identities, whether gendered, racial, ethnic, class determined, place-specific or informed by sexual orientation, remain at the heart of most analyses of Irish film" (8). The identity of Irish film itself is explored here in much the same way an individual or national identity might be. Barton discusses the national cinema in the context of globalisation and transnationalism, attempting to locate a distinctive Irish cinema in an era of co-productions that often defy local or national classifications. Indeed, this is reflected in the films themselves. Barton argues that "within the Ireland that contemporary cinema evokes, place is increasingly contingent. Who may make their own place in the national space or how they can do so is a fraught dynamic that calls into play factors of class, gender and race" (13) and that "Irish cinema is above all engaged with identity politics" (18). Therefore, various categories of identity are returned to and elaborated on throughout the book. 
Barton particularly notes that it is her "intention to foreground representations of women in contemporary Irish filmmaking throughout this book" (20) - something she noticeably achieves. In Acting Irish in Hollywood (2006), Barton commented that "since the revitalization of the Film Board in the early 1990s, Irish cinema has overwhelmingly favoured narratives dedicated to issues of masculinity" (224), and that the lead female roles in many Irish productions were "occupied by imported actors, thus denying rising indigenous performers the opportunity to play on the international circuit" (225). She picks up on this in Irish Cinema in the Twenty-First Century, noting that the recent international success stories of Saoirse Ronan and Ruth Negga "suggest a much greater population of female stars than actually exists" (35). Importantly, Barton brings her focus on gender imbalance to roles behind the camera in the Irish film industry as well. In Chapter 1, she discusses the low percentage of female writers and directors applying for and receiving funding for projects (and acknowledges that these numbers are even worse for ethnic minorities). It is notable that the Irish Film Board (now Screen Ireland) launched a plan to promote gender diversity in the industry through its funding schemes in 2015, and have since seen a rise in funded projects with women directing (from $20 \%$ in 2017 to $36 \%$ in 2018) and writing (from $20 \%$ in 2017 to $45 \%$ in 2018) ("Gender Statistics"). Barton plays close attention to the role these women play in shaping the construction of Irish films throughout the book, alongside interrogations of the representation of women in the nation's cinema.

After outlining the production context of, and setting the scene for, Irish film in Chapter 1, Barton goes on to examine one of the big successes of the Irish film industry in the twenty-first century in her second chapter, "Animating Ireland". This chapter begins by situating animation within the national cinema, noting its ability to "question otherwise fixed identities, reimage space and destabilise linearity", thus functioning in interesting ways that can "destabilise or question paradigms" (43). Barton then breaks down Ireland's animation output into categories of those produced for global television (financially successful) and those concerned with Irish themes and creating a distinctly Irish animation tradition, which draw attention and esteem to Ireland's animation industry, but often make a loss despite critical success. The latter category is Barton's focus in this chapter after sie addresses the history of Irish animation and the country's two leading animation companies - Brown Bag Films and Cartoon Saloon. Using The Secret of Kells (2009) and The Song of the Sea (2014), both produced by Cartoon Saloon and nominated for Academy Awards, Barton considers the invention of a national style of animation that is visually distinct in its $2 \mathrm{D}$, hand-drawn artistry, and that incorporates Irish history and mythology in the modern era.

Chapters 3 and 4 then focus on two additional areas of the Irish film industry that have proven particularly successful in the last few decades, but which have been underrepresented in academic discussion - horror and (creative) documentary. Barton locates the origins of Irish horror with the establishment of Roger Corman's production studio, Concorde Anois Teo, which produced low budget horror and exploitation films in Connemara. Though these films largely contained no Irish themes, Barton notes that most Irish horror films can be positioned as both distinctly Irish and globally recognisable (appealing to larger horror audiences). Indeed, space, place, and the tensions and border-crossings of the local and global - familiar and other - are central to the analysis in this chapter. Drawing on the work of other scholars of Irish horror, such as Emma Radley, who first noted the genre's disruptive potential and links to the changing Ireland of the Celtic Tiger era, Barton aptly explores key themes in Irish horror as representative of cultural fears and traumas: colonisation, late and rapid globalisation and modernisation, race, religion, and the environment. Similar themes are explored in the chapter on documentary film, with a particular focus on "geographically and socially marginalised identities" (92) as well as creative practices in the industry. Not only 
does Barton reflect on the social issues addressed in these films, but the style in which this is done, paying particular attention to the artistic documentaries of Irish auteur Pat Collins.

Following these chapters, Barton enters more well-trodden areas of Irish cinema in Chapters 5-8, which cover history and trauma, Northern Ireland, rural Ireland, and the Irish city on screen. However, she identifies new trends and themes within these areas, including LGBTQ+ cinema, and the shifting portrayals of space and gender in the contemporary period. Important new films are incorporated into Barton's analysis here, including Brooklyn (John Crowley, 2015), pictured on the cover of the book, which is examined as a reworking of the heritage film, and A Date for Mad Mary (Darren Thornton, 2016) and Handsome Devil (John Butler, 2016) as exemplary of new directions in Irish queer cinema. These recent films are not considered in isolation, but in terms of how they are situated within or respond to longstanding trends in Irish cinema, and/or Irish cultural expression and representation more broadly. Through this, Barton clearly demonstrates the various directions that Irish cinema has taken in the twenty-first century thus far, beyond its emergent success stories of animation and horror, and proffers an understanding of how and why constructions of the nation on screen have developed.

Irish Cinema in the Twenty-First Century is a valuable contribution to the area of Irish film studies that marks the changing shape of Ireland's film industry and national cinema during and after the Celtic Tiger. Addressing the nation, and the local, within the frameworks of globalisation and transnationalism, Barton deftly scrutinises the tensions and struggles of identification - individual, spatial, and national - evident in Ireland's films, and in the industry itself. The book offers both a broad overview of key contexts, themes, and genres in Irish film, but also detailed close analyses of exemplary filmmakers and significant films that give shape to what can be considered Ireland's national cinema. An accessible read, and very reasonably priced in paperback and e-book formats, this book will not only prove extremely

useful to students, researchers and lecturers in Irish studies or film studies, but will also interest general readers who want to learn more about these areas.

\section{Works Cited}

Barton, Ruth. Acting Irish in Hollywood: From Fitzgerald to Farrell. Dublin: Irish Academic Press, 2006.

Irish National Cinema. London: Routledge, 2004.

"Gender Statistics". Screen Ireland. 6 January 2019. www.screenireland.ie/about/researchdata.

Radley, Emma. "Violent Transpositions: The Disturbing 'Appearance' of the Irish Horror

Film”. Viewpoints: Theoretical Perspectives on Irish Visual Texts. Eds. Claire Bracken and Emma Radley. Cork: Cork UP, 2013. 109-123.

Loretta Goff recently completed her PhD in Film and Screen Media at University College Cork, where she also teaches. She has published articles in Alphaville: Journal of Film and Screen Media, Persona Studies, and MELUS: Multi-Ethnic Literature of the United States.

loretta.goff@ucc.ie 
The Historical Dictionary of Irish Cinema, $2^{\text {nd }}$ edition.

Tony Tracy and Roddy Flynn

New York: Rowman and Littlefield, 2019. 656 pp.

ISBN: 9781538119570

Reviewer: Stephen Boyd (Institute of Art, Design and Technology, Dun Laoghaire)

The first edition of this book was published in 2007 by Scarecrow and written by Roddy Flynn and Patrick Brereton. Whilst the original edition was 393 pages long, this second edition is 657 pages long which reflects the significant amount of additional material in the text. The Historical Dictionary of Irish Cinema (THDIC) is now published as part of Rowman and Littlefield's fascinatingly eclectic "Historical Dictionaries of Literature and Arts" series of reference texts. Tony Tracy and Roddy Flynn's tome provides the reader with a wider range of entries and references than its previous incarnation whilst also updating existing entries. As the authors note in their preface, "this second edition ... is effectively a new book. It is twice as long, and virtually all of the original entries have been substantially revised or rewritten" (xi). The authors argue for the relevance of the work in the age of the Internet Movie Database and Wikipedia by stating their belief that their dictionary can compile academic knowledge "between two covers in a way databases cannot" (xi).

In their introductory remarks the authors discuss the self-imposed limits they placed on the work regarding what the notion of an "Irish Cinema" actually means within the confines of this dictionary. Tracy and Flynn argue that their choices are "influenced by a common sense definition of a film text: live action, structured by narrative, feature length and intended for big screen exhibition" (ibid). They do not necessarily stick to these definitions; their "common sense" definition therefore still includes entries on some documentary films and documentarians. They also include entries on long discussed American and British productions which often have more substantial entries than some twenty-first-century Irish films. This tendency has become a fixture of the study of Irish cinema from Rockett, Gibbons and Hill's seminal Cinema and Ireland (1987), to McLoone's excellent Irish Film: The Emergence of a Contemporary Cinema (2000) and Lance Pettit's Screening Ireland (2000). The reason for this relates to a relative absence of production in Ireland until the 1970s and 1980s and the consequences of this are eloquently described by Ruth Barton in the essential Irish National Cinema: "if we are to talk of a national cinema ... we have to engage in a series of acts of creative bricolage; that is, to see how an image of Ireland on screen emerged out of the national industries of other countries" (4). The authors follow Rockett's premise in his compilation of The Irish Filmography and engage in similar acts of bricolage in defining what still constitutes an "Irish" film when they include entries on Far and Away (Ron Howard, USA, 1992) or Yves Boisset's 1977 French film The Purple Taxi. The debate over what constitutes an Irish film is far from over. Ruth Barton recently introduced her new book, also reviewed in this issue, with a similar discussion about the merits of Yorgos Lanthimos's The Lobster as an Irish film (1-3). Tracy and Flynn argue that their "broader definition includes mainly American and British pictures that have defined the acceptable limits of how things Irish may be represented" (xi). The authors also recognise that their text is a "mosaic" which is "partial and imperfect" (ibid).

The second edition of The Historical Dictionary of Irish Cinema is easily the most comprehensive and accessible work of reference within the discipline, even if Kevin Rockett's almost 800 page long The Irish Filmography: Fiction Films 1896-1996 still retains excellent research value for its scope and detail. THDIC is aimed at a variety of readers but it will be most useful as a work of reference for researchers, undergraduates or even 
postgraduates approaching the subject for the first time. Apart from the dictionary section, the features of the book include an introductory essay (which will serve as a great introduction to the field for undergraduates), a chronology of relevant events, and a wide ranging bibliography that provides information on many publications within the field. The dictionary entries are broad and varied serving as introductory overviews and including sections on major actors, production and distribution companies, film festivals, cinemas, and filmmaking initiatives and legislation. This edition includes updated and new sections on contemporary filmmakers such as Lenny Abrahamson and John Carney, actors such as Michael Fassbender, Orla Brady, Amy Huberman and Saoirse Ronan, and more recent films such as Zonad (John Carney, 2009), A Date For Mad Mary (Darren Thornton, 2016), and Handsome Devil (John Butler, 2017). An expanded section has also been provided to the burgeoning Irish animation sector and the international successes of the production companies Brown Bag and Cartoon Saloon. The book is particularly useful when discussing areas relating to industrial legislation, filmmaking initiatives, and Irish and European policy with regard to film production. This is reflected in highly informed entries on Filmbase, the Irish Film Board (now Screen Ireland), the Irish Film Institute, and industrial policy such as the Creative Capital report and Creative Europe. Tracy and Flynn also offer brief critical appraisals of many of the film entries

Some interesting people and films have been left out of the book or are not provided with a dedicated entry. For example, although her film Hush a Bye Baby is present, one of Ireland's most important feminist filmmakers, Margo Harkin, is not provided with a dedicated entry although she was deemed worthy of a section in the Wallflower Guide to Contemporary British and Irish Film Directors (2001). Whilst it is true that much of Harkin's work was in television documentary, this is no less true of filmmaker Alan Gilsenan who is provided with a $2 \frac{1}{2}$ page entry in the book. Margo Harkin was also a producer on Joel Conroy's exhilarating narrative driven and highly cinematic surf documentary Waveriders (2008) which does not have an entry in the book. Waveriders was supported by the Irish Film Board and N.I. Screen and is amongst the most successful Irish cinema releases over the last 20 years (Boyd, 2014, 2018).

THDIC is highly comprehensive but the willingness by the authors to broaden the subject matter to provide entries to films such as Braveheart (Mel Gibson, 1995), Captain Lightfoot (Douglas Sirk, 1955), or Barry Lyndon (Stanley Kubrick, 1975) may have resulted in slightly less focus on contemporary Irish films. As Michael Patrick Gillespie argues this kind of focus may ultimately contribute to the myth of a "unitary" Irish cinema (xi -xii) rather than offering a tangible analysis of something culturally "Irish". As a result some contemporary films go unmentioned or are not provided with a full entry, for example, The Honeymooners (Karl Golden, 2003), Get Up and Go (Brendan Grant, 2014), The Truth Commissioner (Declan Recks, 2016), The Lodgers (Brian O’Malley, 2017), The Hardy Bucks Movie (Mike Cockayne, 2013), Sing Street (John Carney, 2016), and Yann Delague's Troubles film '71 (UK, 2014). Also absent is the cult curiosity martial arts film Fatal Deviation (Simon Linscheid, 1998) which is clearly a cinematic film even if it never gained a theatrical release. It could be asked why other British or American films are not included, for example, The Devils Own (Alan J. Pakula, 1997) or Fifty Dead Men Walking (Kari Skogland, 2008), or why a film such as Young Cassidy (John Ford, Jack Cardiff, 1965) should not have its own entry. Irish produced films could now sustain a dictionary such as this regardless of their perceived quality or value.

The authors include a number of Northern Irish films such as Good Vibrations (Barros D’Sa, Leyburn, 2013) as part of their "Irish Cinema" without providing a critical context as to how or why or how these films should be regarded as "Irish" or how differently they may be regarded by audiences in both territories. Brian McIlroy noted the importance of these critical 
contexts almost twenty years ago when he discussed how Northern Ireland's identity is often forgotten within definitions of Irish cinema (17-41). There is an entry on NI Screen but no clarifying entry on Northern Ireland and its relationship with the cinema. Again, it is unclear why some Northern Irish films have been selected over others.

This book is steeped in the collected knowledge of academic works in the field. One of the curious aspects of Irish cinema is the disparity between the relatively small cinematic output of the nation and how comprehensively the field has been studied. Tracy and Flynn's dictionary reflects this comprehensive work and comprises the accumulated research of academics such as Kevin Rockett, Ruth Barton, Luke Gibbons, Harvey O'Brien, and Diog O'Connell, amongst others.

The knowledge presented here, as well as by Ruth Barton in her recent book, is so complete that it could almost be regarded as an intellectual endpoint to the study of the current phase of Irish cinema. As the authors note in their introduction, Irish cinema has become transnational in form (9-12). The era of an Irish National Cinema that involved a nation communicating with itself through the popular form of cinema has passed, if it ever truly existed. Much of what we think of as Irish cinema has become part of global and transnational systems of production. This calls attention to the field of study itself. There are unexplored areas within Irish film studies and these must now be developed in order to progress the discipline.

The Historical Dictionary of Irish Cinema is an excellent contribution to the field by two of the most active scholars in the area of Irish film and media studies. As Barton points out in Irish Cinema in the Twenty-first Century (20), Tony Tracy and Roddy Flynn's annual "Year in Review" of Irish cinema in Estudios Irlandeses is one of the few places in which contemporary Irish cinema is still critically catalogued and it is an important resource within the field. This knowledge and experience has allowed the authors to produce one of the most informed and authoritative reference texts on the subject. This book significantly improves on its predecessor and it will enrich the study of Irish cinema whilst benefiting anyone with an even casual interest in the field.

\section{Works Cited}

Allen, Yoram, Del Cullen and Hannah Patterson. The Wallflower Critical Guide to Contemporary British and Irish Film Directors. London: Wallflower Press, 2001.

Barton, Ruth. Irish National Cinema. London: Routledge, 2004.

. Irish Cinema in the Twenty-First Century. Manchester: Manchester University Press, 2019.

Boyd, Stephen. "Surfing a Postnationlist Wave: The Role of Surfing in Irish Popular Culture". Ireland and Popular Culture. Ed. Sylvie Mykowski. London, Peter Lang, 2014. 211226.

Boyd, Stephen. "No Boarders: Postnational identity and the Surfing Subculture in Ireland". Eds. Paddy Dolan and John Connolly. Sport and National Identities: Globalisation and Conflict. London: Routledge, 2018. 113-128.

Gillespie, Michael Patrick. The Myth of an Irish Cinema: Approaching Irish Themed Films. New York: Syracuse University Press, 2008.

McLoone, Martin. Irish Film: The Emergence of a Contemporary Cinema. London: British Film Institute, 2000.

Petitt, Lance. Screening Ireland: Film and Television Representation. Manchester: Manchester University Press, 2000. 
Rockett, Kevin, Luke Gibbons and John Hill. Cinema and Ireland. London and New York: Routledge, 1987.

Rockett, Kevin. The Irish Filmography: Fiction Films 1896-1996. Dublin: Red Mountain Media, 1996.

Stephen Boyd is a Lecturer in Film and Digital Media studies at the Institute of Art, Design and Technology (IADT), Dun Laoghaire. He is also a film critic and commentator for Arena on RTÉ Radio 1 and has taught education courses at the Irish Film Institute. His research focuses on the use of film, cinema and digital media in the Irish surfing subculture.

stephen.boyd@iadt.ie

\section{A Post-Nationalist History of Television in Ireland. Edward Brennan \\ New York: Springer, 2019. 235 pp.}

ISBN: 978-3-319-96859-9

\section{Reviewer: Stephen Goulding (Ulster University)}

That mass media played a formative role in the development of nations is held as a wellestablished, if not self-evident, premise by scholars of both media history and nationalism studies alike. Underpinning core works in these fields is the contention that, as modernity progressed, the enhanced capacity of mass media to reach increasingly larger audiences aided the fostering of a collective sense of belonging amidst a dispersed populace. As such, the literature credits mass media as a unifying conduit for states: a means through which a cohesive, national collective could be constructed and maintained. Benedict Anderson (1983), for instance, held the printing press to be a key tool in the process of nation formation: a communicative framework through which imagined communities could sustain a sense of belonging and connectedness. Put simply, in the literature, mass media are touted as nation builders. Works of media history are seemingly beholden to this focus on the nexus between nationhood and media, insofar as they typically take the national as their unit of analysis.

However, adopting these "nation-blinkers", poses some limitations on a holistic consideration of a broadcast medium like television which, from its relatively early incarnations, could reach transnational audiences. Moreover, television began to take hold in an era characterised by increasing technologization and social progression, often in response to international social or economic trends. Yet, histories of broadcasting media have perpetuated an academic ethnocentrism and often treat the "nation" and the "national audiences" as synonymous. Moreover, they tend to prioritise institutional centres of power over sources less central to the broadcasting process. In doing so, they omit insights from one key perspective: that of the masses who engaged with radio and television in their nascency. Institutional tales and gossip have, thus far, been prized over the lay-perspective as academic sources. In this regard, the history of television in Ireland is no exception: so argues Edward Brennan in his latest book, A Post-Nationalist History of Television in Ireland (2019, Springer). Brennan, a lecturer in Media at the newly fledged Technological University of 
Dublin, sets out to address this inadvertent nationalism of Irish media history, unwittingly reproduced by academics and institutions.

Departing from the contention that the history of television in Ireland - as it is documented in the current body of literature - is largely the history of Radió Telifís Eireann's (RTÉ) (the semi-state broadcaster) embracement of the medium, Brennan challenges the institutional history that has been informed by sources "from above" or "from the side". This orthodox history tells a narrative of emancipation and of social change. It follows well established, international tropes (Curran 2009) with subtle Irish nuances: A new medium ushered in a new epoch; the old Ireland gave way to a fledging, modern nation; the conservative, Catholic bedrock of the Irish psyche slowly began to dissipate, as a nation mired in a sociocultural torpor collectively broadened its social horizons through the new medium. A new national identity emerged in opposition to the vilified, old-Ireland, embodied respectively by the paragons of de Valera and Lemass. History, thus far, has positioned RTÉ at the epicentre of this social upheaval.

For Brennan, however, drawing on sources "from above" or "from the side" cannot adequately account for the medium in its entirety. Aspects such as Irish people's early perceptions of television, their reactions to its arrival, or the changes in behaviour undertaken by them in order to integrate television into the social fabric of mid $20^{\text {th }}$ century Ireland are not prioritised in top-down histories. The grassroots, constituent social changes which enabled television to become "the new normal" are elided in such institutional narratives. Additionally, these accounts often ignore, or afford a peripheral focus to, engagements with pre-RTÉ television, such as the early broadcasts from the BBC or UTV accessible only to those in certain parts of the nation. Orthodox histories prioritise discussions of the social impact of indigenous content (chiefly the Late Late Show), yet neglect the multitude of internationally produced spectacles like The Fugitive which Irish audiences tuned into with devout intrigue. Moreover, their constriction to national parameters eschews a thorough consideration of Ireland as a nation which found itself at the behest of two, powerful spheres of influence in the global world of television: the USA and the UK. Both nations exerted, albeit indirectly, some influence over the form and fruition of Irish television and broadcasting in general. Irish television not only inherited past-its-best content from both nations, but also aspects of both nation's commercial and public-service broadcasting models. These are inheritances which informed, influenced and, ultimately, shaped Irish people's perceptions of television: observations and nuances which have remained unaddressed by academic literature thus far.

To address this gap in the literature, Brennan proposes a method hereto disregarded by scholars of Irish media history: life-story interviews. Such interviews aim to elicit personal narratives from interviewees. They aim to "generate an account of a person's past where television is a feature, but not the exclusive focus" (60). Brennan's approach relies on a conceptualisation of memory as a malleable and subjective entity, influenced by social position and culture. It conceives of recollection, not as reliable reproductions of the past, but as a part of personal identification: that is to say, "people announce their pasts in a manner that preserves their identity and that is likely to maintain or improve their social standing" (47). These recollections are imbued with shared values and subject to social power. As such they provide useful data for uncovering the social currents which governed early interactions with the medium, which are veiled from institutional approaches. Brennan's "from below" approach provides key insights into how early access to (and interactions with) television were influenced by variables such as gender, class and education. It elucidates the shifting social attitudes toward a medium initially hailed as a hallmark of modernity, but quickly became tarnished by stigma and class snobbery. In essence, Brennan provides a new layer of consideration for the study of television in Ireland and reveals what were hitherto beneath the 
surface social aspects of the medium, through recollections which might otherwise have been lost to the ravages of time. In doing so he challenges the orthodox, technologically deterministic account of social change in Ireland.

Brennan's early chapters outline the dominant, institutionally oriented narrative of Irish television and provide a theoretical framework for the use of memories and recollection to address the pitfalls associated with it. He then draws from newspaper representations to gauge the Irish public's early perceptions of the medium, which largely reflected a global hopes and fears discourse. Subsequent chapters draw on interview data to examine Irish people's recollections of television uses and imported content; or concentrate on television's role in the transformation of social space and time in the mid- $20^{\text {th }}$ century Irish home and the medium's dynamic relationship to social class. The book concludes with reflections on insights uncovered over its course and the expedience of its methodology in adding to existing media histories literature.

And therein lies its greatest contribution to research, its capacity to address the shortcomings of current media history in Ireland - its institutional biases and inadvertent nationalism. This ability is succinctly exhibited in the book's penultimate chapter, in which Brennan questions the significance of the often-cited 'Bishop and the Nightie' incident of 1966. The incident - in which an audience member of the Late Late Show purportedly caused public consternation after joking that she had not worn a nightdress on the night of her wedding, causing a catholic Bishop's condemnation to make front-page news the following day - is held in the literature to be a microcosm of a much wider social agonism: a defining moment in Ireland's embracement of television and modernity. However, life story interviews conducted by Brennan revealed the incident to be of peripheral importance, at most, to interviewees; exposing the mythical status afforded to the incident by institutions and the academy. This book's argument provides ample food-for-thought and warrants a reconsideration of the widely disseminated, RTÉ-centric account of television (and social change) in Ireland. Whilst it must be conceded that there are limitations regarding generalisations of findings (the author himself concedes that these findings are "based on limited data" (157), Brennan's research has begun to enlighten levels of the history of television in Ireland that were hereto neglected. His findings point toward the need for further research in this area and the necessity to capitalise on what is a diminishing academic resource: the memories and recollections of the medium's early enthusiasts and interactants.

A Post Nationalist History of Television in Ireland makes a valuable addition to current research and enhances our understanding of the relationship between television, the global and social change in an Irish context. While the volume could be of obvious benefit to academics in media studies, history and sociology to name but a few, Brennan's discussion may also prove of interest to those with a general interest in social change in Ireland or the impact of television on Irish society.

\section{Works Cited}

Anderson, Benedict. Imagined Communities. Reflections on the Origin and Spread of Nationalism. London: Verso, 1983.

Curran, James. "Narratives of Media History Revisited". Narrating Media History. Ed. Michael Bailey. Routledge: London, 2012. 25-45.

Stephen Goulding is a Department for the Economy International funded PhD Researcher at the School of Communication and Media, Ulster University, and a member of the Centre for 
Media Research. He holds a BA (Hons) in English Literature and Philosophy from University College, Cork (NUI) and an MA in Speech \& Language from Queen's University, Belfast.

goulding-s@ulster.ac.uk

Media Law in Ireland, $2^{\text {nd }}$ edition.

Eoin Carolan and Ailbhe O'Neill.

London: Bloomsbury Professional, 2018. 688 pp.

ISBN: 9781784518004.

\section{Reviewer: Maria O’Brien (Dublin City University)}

The legal concepts pertaining to the production, distribution and consumption of media are of significance given the important role of the media in a democratic society. Recently, public debates on such issues as blasphemy, the funding of public service media, and regulation of political advertising illustrate the significance of these media law issues to wider society. This is a fast-developing and ever-changing area of law, and thus the second edition of this book is welcome. Neither law nor the media operate in a political or social vacuum but draw on issues ranging from constitutional law, politics, and the philosophy of the nature and operation of a democracy.

The second edition of Media Law in Ireland by Eoin Carolan and Ailbhe O'Neill is a practically focused text aimed at legal practitioners, students, and academics. Primarily, it explicitly and deliberately focuses on what is traditionally known as the Fourth Estate; that is, the more traditional forms of broadcast and journalistic media. The pragmatic decision not to extensively cover law as it applies to new media is, according to Carolan and O'Neill, justified by the speed of developments in this area.

The authors emphasise the balancing act between the protection of free speech, the freedom of the press, and the role of the state towards the operation of the media. Media Law in Ireland approaches the subject matter in a comprehensive fashion, offering an in-depth, insightful analysis of the legal issues pertaining to media law from an Irish and EU perspective (and international where relevant). Significantly, it combines this analysis with an overarching conceptualisation of the fundamental theoretical concepts shaping our understanding of media law. This is illustrated by the thematic nature of the book, which, usefully insists on foregrounding the significance of media to democracy and society.

The authors' insightful approach to the wider social and political significance of the legal issues relating to media is illustrated by the framing of the law in this area around the fundamental issues of theories of freedom of expression as covered in Chapters 1 and 2. The provision of this theoretical lens through which legal issues around media are explored underpins the subsequent chapters. Further into the book, the framing of the intersection of media and politics in Chapter 4 and the media and courts in Chapter 5 illustrate the holistic nature of this approach. These chapters provide a foundation beyond normative legal concepts to interrogate the development of defamation law, privacy and regulation of the press and broadcasting, covered in Chapters 6, 7, 8 and 9 respectively. Throughout, the development of legal jurisprudence from an Irish, UK and European perspective is placed in a well-illustrated, wider social and political context. 
The legal requirements governing political advertising offers a contemporary illustration of the present-day relevance of media law issues. For example, the (problematic) announcement by Twitter on 20 October 2019 that they will not accept political advertising ${ }^{1}$ raises questions around the legislation in Ireland banning political advertising on broadcasting (a ban that does not extend to print or internet). The ban, contained in s 41(3) of the Broadcasting Act 2009, provides that "a broadcaster shall not broadcast an advertisement which is directed towards a political end". As Carolan and O'Neill state, apropos of the disquiet in Ireland over the use of social media as a campaigning tool during the referendum to remove the 8th Amendment (i.e., relating to the constitutional ban on abortion) from the Irish Constitution, "whether such self-regulatory measures are appropriate or sufficient" is "questionable in an era in which news and current affairs consumption is increasingly realised through social media and other online sources" (147). The exploration of the significance of the decisions of the European Court of Human Rights (ECHR) under Article 10 of the European Convention on Human Rights (ECtHR) (such as Tierfabriken I and II and TV Vest) ${ }^{2}$ illustrates both the breadth of knowledge of the authors of Irish and EU law but also the international nature of legal developments in this area and the political significance of such decisions.

As indicated above, the authors explicitly state that they do not cover legal issues around new media forms, holding that while the "ever-shifting nature of the media environment" (preface v) means that the range of potential legal issues expands to include a multitude of other areas, their focus is upon the law as it impacts on media in the more traditional sense. Nevertheless, the authors correctly eschew technological determinism in their application of the law to newer forms of media where appropriate. For example, Chapter 6 on the law pertaining to defamation refers to online issues where appropriate throughout the chapter, while also addressing the distinct characteristics of defamation online. It is not a criticism of this book to express a hope that the authors will, in future editions, expressly apply their insightful approach to media law to new forms of media. Rather, it is an acknowledgement of their extensive knowledge and comprehensive understanding of the complexity of the multiple legal and regulatory issues arising out of engagement with forms of media from the perspective of the creator and consumer.

Media Law in Ireland at times echoes the emerging approach in legal scholarship of law and political economy (LPE), given its recognition of the relevance of power structures (most particularly in concepts of broadcasting regulation and media ownership). LPE "focuses on how relations of power are legally and politically configured and reconfigured over time and in distinct periods, and how in turn this conditions the development of the economy" (Wilkinson and Lokdam 2). The coverage of media ownership in Chapter 10, which references the Media Pluralism Monitor 2017 carried out by Roddy Flynn is a particularly interesting example of the potential intersection of law and political economy as it pertains to the discourse around forms of media.

This book is a welcome addition to the field of media law books, complementing Cox and McCullough's Defamation: Law and Practice from 2014, and the recently published UKfocused Media \& Entertainment Law by Ursula Smartt ( $4^{\text {th }}$ edition, 2020) for example. This is an invaluable resource for practitioners and academics, but should also be referenced by those with interest in political economy of communications or media industries regulation. While the text is aimed at legal practitioners and law students, it is also an example of the potential richness of interdisciplinary approach between law and political economy.

The regulatory and political decisions which shape law-making towards the media are not made in an economic or social vacuum but are part of wider society. Analysis of our media needs grounding in legislative and regulatory concepts to further understanding of the wider context within which all forms of media are produced, disseminated and consumed. 
The insightful analysis of media law issues contained in Media Law in Ireland reflects the importance of mediated forms of communication to our daily lives.

\section{Notes}

1 As announced by Twitter CEO @jack on twitter on 30 October 2019 https://twitter.com/jack/status/1189634360472829952.

2 VgT Verein Gegen Tierfabriken v Switzerland (2002) 34 EHRR 4; VgT Verein gegen Tierfabriken $v$ Switzerland (No 2) (Application No 32772/02), Grand Chamber, 30 June 2009; TV Vest As \& Rogaland Pensjonistparti v Norway (2009) 48 EHRR 51.

\section{Works Cited}

Cox, Neville and Eoin McCullough. Defamation: Law \& Practice. Dublin: Clarus Press, 2014.

Flynn, Roddy. Monitoring Media Pluralism in Europe: Application of the Media Pluralism Monitor 2017 in the European Union, FYROM, Serbia \& Turkey. Country Report: Ireland. ("Media Pluralism Monitor 2017").

Smartt, Ursula. Media \& Entertainment Law. $4^{\text {th }}$ Edition. London: Routledge, 2020.

Wilkinson, Michael and Hjalte Lokdam. Law and Political Economy. LSE Law, Society and Economy Working Papers 7/2018. London School of Economics and Political Science, Law Department.

Maria O'Brien has recently completed her $\mathrm{PhD}$ in the School of Communications in Dublin City University. Her PhD thesis is entitled A Political Economy of State Aid for the Audiovisual Industries in Ireland: A Cultural Policy Research Perspective on Section 481. Her research interests include the intersection of law and political economy within the cultural and creative industries, with a focus on media industry research from both a national and European perspective.

maria.obrien227@mail.dcu.ie

Gaelic Games on Film: From Silent Film to Hollywood Hurling, Horror and the Emergence of Irish Cinema.

Seán Crosson.

Cork: Cork University Press, 2018. 242 pp.

ISBN: 9781782052470

\section{Reviewer: Denis Condon (Maynooth University)}

The appearance of Seán Crosson's Gaelic Games on Film prompts the contradictory reactions that it seems like an event both long overdue and improbable. On the one hand, it seems incredible that it has taken until cinema's $125^{\text {th }}$ year for a book to appear devoted to the relationship of the twentieth century's dominant medium to the sports promoted by Ireland's key indigenous sporting organization, the Gaelic Athletic Association (GAA). On the other 
hand, one might wonder if enough material exists for such a book, given the dearth of indigenous film production for much of the twentieth century and the GAA centrality to a cultural nationalist project that was very often isolationist and hostile to imported popular culture that the cinema frequently epitomized. Crosson's meticulous and carefully argued book convincingly addresses that second reaction by demonstrating that Gaelic games and cinema crossed paths in several different ways in the course of the century and more that the book covers. The fact that those encounters were only rarely in fictional features films requires Crosson to employ a mobile form of analysis that is attentive to quite different encounters between cinema and Gaelic games at different times.

In part a book on the topic has awaited a scholar with Crosson's particular skills in film studies and sports studies. Over the past decade, he has written not only several directly relevant scholarly articles on Irish sports films and screening notes for the Irish Film Institute's GAA Gold DVD series but also a monograph on sport and film internationally. That previous work is brought to bear coherently and effectively here in what is essentially an alternative history of Irish cinema seen from the perspective of its encounter with native sports. But it is also something more than this. Alongside the forms of analysis with which film studies scholars will be familiar are sports studies modes of inquiry that may be less familiar and that are here evident in discussions of the success of filming techniques in capturing styles of play, famous games and the technique of well-known players.

The book's eight substantive chapters analyze the filmic representation of Gaelic games - Gaelic football, hurling and camogie - from the 1900s to the early twenty-first century. There are, it seems, no substantial representations on film of Gaelic handball or rounders, two of the less frequently played games falling under the GAA's remit. Although the book's subtitle is lengthy, even quite comprehensive, a clarification of what is meant by "film" here may be useful, given the virtual disappearance of film stock as a medium on which moving images are captured. Of course, historically this was not the case, and the book pursues its subject from the earliest known representations of Gaelic games in moving images on film to such recent, digitally shot features as Dead Meat (2004). So, although the book encompasses image formats beyond film stock, the word film is important to the book's perspective both because it locates itself firmly as a work of film studies by referencing so much work in the area and because Crosson is careful to point out that the book does not deal with televised coverage of Gaelic games, a subject that he indicates still needs to be fully explored. Indeed, television is mentioned mostly in passing, and is only addressed in any detail in the conclusion's analysis of the broadcasting of Laochra, the GAA's spectacular event at Croke Park to commemorate the centenary of the 1916 Rising. While acknowledging that television and online platforms provide the main ways that people now see Gaelic games, Crosson nonetheless argues that television coverage has adopted cinematic modes of representation that can be seen in the newsreels, documentaries and feature films that the book analyzes.

Initially and until television took over the role in the 1960s, the cinema was the place to which spectators went to see highlights from matches presented on screen. Even before the marshalling of Catholic nationalist ideological opposition to cinema generally in the late 1910s, local cinema owners and filmmakers quickly identified the advantages of filming such popular sports meetings. Important matches, particularly the football and hurling finals, became a staple of both indigenous and foreign newsreel companies operating in Ireland, and although the representation by British companies could be problematic, newsreel coverage of Gaelic games was largely positive. And Crosson observes that while the GAA was itself one of the most important cultural nationalist organizations, it facilitated the filming of its games because it recognized the value of cinema in promoting its activities. 
The nuances of this somewhat symbiotic relationship are well illustrated in the book's opening chapters "Gaelic Games in Early Cinema" and "Gaelic Games in the Newsreel Era". The relationships become more fraught in the third and fourth chapters, where foreignproduced films of the 1930s-1960s are the focus, before the book returns in the latter four chapters to indigenously produced films made between the late 1940s and the 2000s. By the third chapter "Hollywood Hurling: Representing Gaelic Games in American Cinema, 193060 ", hurling, far more so than Gaelic football, comes to be the quintessential filmic Gaelic game. This was the case for Irish fiction filmmakers too. The opening early cinema chapter shows that hurling features prominently in the Film Company of Ireland's Knocknagow (Fred O'Donovan, 1918), where it was the favourite pastime of the film's hero, Matt the Thrasher. Because so few other fiction films were made by indigenous filmmakers for much of the rest of the twentieth century, representations of hurling in mid-century were by Hollywood filmmakers, including John Ford in The Rising of the Moon (1958) and Young Cassidy (1965). In an argument that will be familiar from Irish film studies work on Ford, Crosson argues that Ford's representation of hurling as violent is a self-conscious unmasking of Irish stereotypes that are seen in an unself-conscious form in earlier Hollywood films, perhaps most explicitly in the non-fiction short Hurling (1936), whose ironic commentary on a hurling match exaggerates the likelihood that players will experience serious injury. Chapter 4 is devoted to 1958 British film Rooney (George Pollock), "one of the few films that features a hurlingplaying lead protagonist", albeit that he is played by Liverpool-born John Gregson (90).

While chapters 2-4 treat the variety of representation of Gaelic games offered by foreign filmmakers from the 1920s to the 1960s, the book's final four chapters deal with indigenous representations from the 1940s to the 2000s. Chapters 5 and 6 examine newsreels and other non-fiction films made by the National Film Institute of Ireland (later the Irish Film Institute) and the Irish-language cultural organization Gael Linn. While these chapters show how depictions of Gaelic games were "an important cultural resource in affirming Irish identity and established conceptions of the Irish nation" (139), Chapter 7, "The Critical Turn: Gaelic Games in Film between the 1960s and 1980s", turns to films that scrutinize constructions of Irish identity favoured by the state and other parts of the establishment. In common with much of the work produced by filmmakers involved in the critically engaged Irish cinema that emerged from the 1970s, Crosson shows that Peter Lennon's 1968 documentary Rocky Road to Dublin and Fergus Tighe's 50-minute drama Clash of the Ash (1987) perform a postnationalist demythologizing of Gaelic games. Although Chapter 8 " The Hurley Is the New Chainsaw': Gaelic Games in Contemporary Cinema" also considers Pat Comer's documentary A Year 'Til Sunday (1998) and makes brief mention of such wellknown features as Michael Collins (Neil Jordan, 1996) and The Wind that Shakes the Barley (Ken Loach, 2006), it engages most substantially with the 2004 horror film Dead Meat (Conor McMahon). As such, it participates in Irish film studies remarkable reassessment of the horror genre, which many critics formerly dismissed as too trivial to deserve attention. In Dead Meat, Crosson convincingly argues, "hurling functions as a protective motif against the onslaught of voracious global capitalism" (172).

The text's insightful reading of films and institutions is accompanied by 41 Illustrations, many of them screengrabs from the films being discussed but others are newspaper advertisements, photographs of figures featured in the text, film posters, reproductions of documents and memorably, a Fianna Fáil election campaign poster featuring Bertie Ahearne. The publisher is to be congratulated for agreeing to the inclusion of so many images in the book, albeit that one or two of them could be reproduced more clearly. Apart from that quibble, the book is handsomely produced in a reasonably priced hardback edition. It will hopefully also appear in a paperback edition soon because although it operates through 
academic modes of discourse, it is lucidly written and addresses a topic that makes it likely that it will be sought out by non-academic readers interested in sport in general and the GAA in particular.

Denis Condon lectures on cinema at the Departments of English and Media Studies, Maynooth University, Ireland. His research focuses on early cinema, and his publications on this subject include the book Early Irish Cinema, 1895-1921 (2008), and articles in such journals as Early Popular Visual Culture, Screening the Past, Alphaville and Field Day Review. He is currently working on a monograph on Ireland's First Cinemas and co-editing a collection on music and visual culture. He also runs a research blog at https://earlyirishcinema.com/.

denis.j.condon@mu.ie 